\title{
PELATIHAN DAN PENDAMPINGAN PEMBUATAN MEDIA PEMBELAJARAN POWTOON PADA GURU-GURU DI LINGKUNGAN GUGUS I BOGOR TENGAH KOTA BOGOR
}

\author{
Elly Sukmanasa $^{1)}$, Lina Novita ${ }^{2)}$, Aries Maesya ${ }^{3)}$ \\ 1,2Program Studi PGSD Universitas Pakuan \\ ${ }^{3}$ Program Studi Ilmu Komputer Universitas Pakuan
}

\begin{abstract}
Abstrak
Peranan guru sangat diperlukan untuk membantu siswa dalam proses belajar mengajar agar materi dapat dipahami secara optimal. Seorang guru tidak hanya semata mengajar di depan kelas saja, tetapi harus bisa menginspirasi siswa. Proses pelaksanaan pembelajaran dalam Kurikulum 2013 memerlukan kemampuan guru dalam bidang IT terutama dalam pembuatan media pembelajaran yang mudah dan menarik karena pembelajaran dalam kurikulum 2013 terdiri dari kegiatan mengamati, menanya, menalar, mencoba dan mengkomunikasikan. Penilaian yang dilakukan pada kurikulum 2013 mencakup tiga ranah yaitu afektif, kognitif, dan psikomotor. Tujuan dalam pengabdian kepada masyarakat ini adalah untuk melakukan pendampingan pembuatan media pembelajaran powtoon pada pembelajaran kurikulum 2013 tematik untuk kelas V Sekolah Dasar Gugus 1 Kota Bogor. Pendampingan ini mendapatkan respon positif terbukti dengan antusiasme guru dalam mengikuti dari awal sampai selesai. Meskipun peelatihan pendampingan ini berbeda dari biasanya, yaitu menggunakan media online atau Webinar karena adanya Covid-19. Pada saat pemberian materi tentang pengenalan program powtoon ini, para guru banyak belajar, karena program ini merupakan program yang baru dikenal. Antusiasme dan kesiapan para guru menandakan adanya motivasi untuk menumbuhkan keaktifan siswa dalam belajar.
\end{abstract}

Kata kunci : Pelatihan, Pembuatan Powtoon, Kurikulum 2013

\begin{abstract}
The role of the teacher is needed to help students in the learning process so that the material can be understood optimally. A teacher is not just teaching in front of the class, but must be able to inspire students. The process of implementing learning in the 2013 curriculum requires the ability of teachers in the IT field, especially in making learning media easy and interesting because learning in the 2013 curriculum consists of observing, asking, reasoning, trying and communicating. The assessment conducted in the 2013 curriculum includes three domains, namely affective, cognitive, and psychomotor. The purpose of community service is to in making media powtoon learning in the thematic 2013 curriculum learning for class $V$ of the Cluster 1 Elementary School in Bogor City. This assistance gets a positive response as evidenced by the enthusiasm of the teacher in following from beginning to finish. Although this mentoring training is different from usual, using online media or webinars because of Covid-19. When giving material about the introduction of the Powtoon program, the teachers learned a lot, because this program was new. The enthusiasm and readiness of the teachers signifies motivation to foster student activity in learning.
\end{abstract}

Key words : Training, Making powtoon, curriculum 2013

Correspondence author: Lina Novita, linovtaz@gmail.com, Bogor, Indonesia

This work is licensed under a $C C-B Y-N C$ 


\section{PENDAHULUAN}

Pembelajaran merupakan suatu proses membelajarkan siswa. Pembelajaran sebagai suatu proses memiliki unsur-unsur yang saling berhubungan satu dengan lainnya. Hubungan unsur satu dengan lainnya akan menjadikan pembelajaran menjadi satu kesatuan yang utuh. Diantara unsur-unsur tersebut yang berkaitan dengan pelaksanaan pembelajaran adalah tujuan, proses pembelajaran terdiri dari materi ajar, metode, sumber belajar dan media pembelajaran, evaluasi pembelajaran serta pelaku pembelajaran, yaitu guru dan siswa. Namun terkadang proses pembelajaran sering mengalami masalah atau hambatan seperti kurikulum yang berganti atau berubah. Perubahan atau pergantian kurikulum ini dibuat dengan sengaja dengan tujuan untuk meningkatkan mutu atau kualitas pendidikan.

Pembelajaran yang aktif dapat terjadi dengan adanya bantuan media. Namun pada kenyataannya media yang ada kurang dimanfaatkan oleh guru. Hal ini merupakan salah satu faktor yang mengakibatkan kebosanan siswa pada saat belajar. Kondisi ini menjadi permasalahan yang terus berkelanjutan, karena guru kurang melakukan inovasi terutama dalam pengadaan media pembelajaran.

Proses pelaksanaan pembelajaran dalam Kurikulum 2013 membutuhkan kompetensi bahwa seorang guru harus menguasai IT secara paripurna karena dimulai dari pembuatan perangkat pembelajaran pada kurikulum 2013 sangat erat kaitannya dengan penggunaaan IT. Demikian halnya dengan penggunaan media pembelajaran, guru dituntut untuk membuat media pembelajaran yang tidak hanya media berbasis non proyeksi tetapi dituntut pula berbasis proyeksi yang disesuaikan keadaan era globalisasi yang syarat dengan teknologi. Proses pendekatan pada pembelajaran Kurikulum 2013 untuk siswa Sekolah Dasar sangatlah komplek dan berkesinambungan yaitu tematik terpadu, pembelajaran yang berdasarkan tema, pendekatan Saintifik yang dikenal dengan pengalaman belajar pokok: menanya, mengumpulkan informasi, mengasosiasi, dan mengkomunikasikan. Demikian halnya dengan penilaian yang dilakukan sangat lebih luas dari pada kurikulum sebelumnya yaitu mencakup tiga ranah aspek kemampuan: afektif, kognitif, dan psikomotor. Itu semua merupakan upaya yang bertujuan untuk meningkatkan kulitas pendidikan di negara kita ini. Penelitian yang sudah dilakukan menunjukkan adanya permasalahan mengenai kurang aktifnya siswa (Ariyanto, dkk. 2018, Novita, dkk., 2019, Sukmanasa, dkk., 2017). Penelitian lain yang dilakukan mengenai pentingnya media pembelajaran dengan metode eksperimen, menunjukkan perlu adanya pengembangan media pembelajaran sesuai dengan materi serta perlu dikembangkan dalam penerapan kurikulum 2013 (Fajar, dkk., 2017, Andrianti, dkk., 2016)). Selanjutnya penggunaan media pembelajaran berbasis digital diteliti oleh Nurdiansyah (2018), Ponza, dkk. (2018) dan juga Awalia, dkk. (2019), juga meninjau permasalahan mengenai siswa yang kurang aktif dalam pembelajaran, sehingga hasil belajar tidak sesuai dengan KKM.

Ketidakaktifan siswa diakibatkan dari rasa jenuh belajar dengan proses pembelajaran yang monoton dan komunikasi yang hanya dilakukan hanya satu arah. Dikatakan demikian karena guru hanya menerangkan atau hanya memberikan tugas mengisi lembar kerja siswa (LKS). Seperti diketahui pada buku pembelajaran kurikulum 2013 muatan materi pembelajaran cenderung sedikit, dapat mengakibatkan ketidakpahaman siswa atau bahkan guru itu sendiri (Muslimin, 2017, Fitriyani, 2019). Guru masih bingung dengan materi ajar yang dapat dianggap kurang sehingga untuk menggunakan media yang memiliki tujuan untuk menarik minat atau motivasi siswa pun 
tidak dapat dilakukan. Ketidakpahaman guru terhadap kurikulum 2013 dan kurangnya penggunaan media pembelajaran dapat berdampak pada proses pembelajaran. Apabila kondisi tersebut terjadi, akibatnya siswa tidak memiliki keinginan untuk belajar, maka kualitas pembelajaran pun akan menurun.

Kurangnya minat siswa dalam belajar tidak terlepas dari peran guru dalam menggunakan media ketika proses pembelajaran berlangsung. Minat siswa dalam belajar tergantung dari kreativitas guru dalam memanfaatkan media yang disesuaikan dengan materi pelajaran. Cara guru dalam menggunakan media harus sesuai dengan materi pelajaran, dan sesuai dengan metode pembelajaran. Hal ini disebabkan karena media yang dibuat belum tentu cocok atau sesuai dengan materi yang akan diajarkan. Dalam hal ini guru harus lebih kreatif dalam memanfaatkan dan mengembangkan media pembelajaran yang ada.

Penentuan prioritas permasalahan yang harus dicarikan penyelesaiannya dari awal dilakukan oleh Tim Pengusul yaitu:

1. Solusi keterbatasan fasilitas maupun sarana dan prasarana proses belajar, dilakukan dengan pendampingan dan fasilitasi yang sinergi antara pihak sekolah dan komite sekolah untuk mendapat bantuan berupa alat/media pembelajaran.

2. Solusi yang ditawarkan mengenai keterbatasan sekolah dalam pengadaan media pembelajaran yang berbasis ilmu pengetahuan dan teknologi yang inovatif, dilakukan melalui pendampingan dan falitasi untuk mendapat bantuan berupa LCD dan Komputer.

3. Solusi mengenai keterbatasan guru yang belum memiliki kompetensi dalam menggunakan media pembelajaran yang efektif, dilakukan melalui pelatihan pembuatan media pembelajaran berbasis ICT.

4. Solusi yang ditawarkan dalam proses pembelajaran kurikulum 2013 dengan pendekatan saintifik, yang menuntut guru untuk menguasai IT dalam mendesain perangkat pembelajaran, yaitu dengan pendampingan pelatihan pembuatan media pembelajaran berbasis ICT.

5. Solusi yang ditawarkan untuk permasalahan kemampuan dan penguasaan alternatif model-model pembelajaran inovatif yang harus diterapkan pada kurikulum 2013, pelatihan pengenalan model-model pembelajaran.

6. Solusi yang ditawarkan untuk permasalahan kemampuan penguasaan guru Sekolah Dasar dalam mempersiapkan dan penggunaan media pembelajaran yang berbasis IT, yaitu melalui pendampingan pembuatan media pembelajaran Powtoon.

Media pembelajaran diperlukan untuk mencapai tujuan pembelajaran agar terdapat efisiensi dan efektifitas dalam belajar. Jika dilihat dari arti kata, media merupakan kata "medium" yang memiliki arti sebagai perantara atau pengantar. Artinya media merupakan perantara atau pengantar pesan dari orang pemberi informasi ke orang kedua sebagai penerima informasi tersebut. Sedangkan menurut para ahli lain, menggunakan istilah media pembelajaran sebagai "teaching material" atau instruksional material, artinya identik dengan pengertian keperagaan yang berasal dari kata "raga", yaitu suatu benda yang dapat diraba, dilihat, didengar dan yang dapat diamati melalui indera manusia.

Para ahli memberikan rumusan pengertian yang berbeda dalam memberikan arti media pembelajaran. Masing-masing memiliki wawasan dan orientasi yang berlainan, namun demikian pada prinsipnya ada kesamaan pengertian yang mendasar dari pendapat atau teori tersebut. The Association Communication and Technology (AECH, 1977) menyatakan bahwa media adalah apa saja yang digunakan untuk menyalurkan informasi. 
Sementara, menurut Suparman (2010), media merupakan alat yang digunakan untuk menyalurkan pesan dan informasi dari pengirim pesan kepada penerima pesan. Selanjutnya Mc.Luhan (2008) memaknai media sebagai saluran informasi.

Dengan demikian menurut Novita dan Sutisna (2020) media pembelajaran sudah selayaknya digunakan dalam pembelajaran, karena media merupakan salah satu alat yang digunakan untuk menarik memperjelas informasi yang disampaikan pendidik dalam pembelajaran. Sebagai alat bantu, media diartikan sebagai bagian yang tidak terpisahkan dan tentu saja harus sesuai dengan proses pembelajaran secara menyeluruh. Dengan kata lain pemilihan media adalah penggunaaan media yang memungkinkan peserta didik dapat berinteraksi dengan media yang dipilih. Powtoon merupakan salah satu media pembelajaran yang dapat dijadikan alternatif untuk memotivasi siswa dalam belajar. "Powtoon" merupakan layanan online untuk membuat sebuah paparan yang memiliki fitur animasi sangat menarik diantaranya animasi tulisan tangan, animasi kartun, dan efek transisi yang lebih hidup serta pengaturan time line yang sangat mudah.

Hampir semua fitur dapat diakses dalam satu layar membuat "Powtoon" mudah digunakan dalam proses pembuatan sebuah paparan. Paparan yang memiliki built-in karakter kartun, model animasi dan benda benda kartun lainnya membuat layanan ini sangat cocok digunakan untuk membuat media ajar khususnya untuk para pelajar yang suka dengan suasana santai dan non formal dalam pembelajaran di kelas.

Dapat disimpulkan bahwa media pendidikan atau pengajaran adalah sesuatu yang dapat digunakan untuk menyalurkan pesan dari pengirim ke si penerima guna merangsang pikiran, perasaan, perhatian, dan kemauan peserta didik, sehingga dapat mendorong terjadinya proses belajar. Sebagai pembawa (penyalur) pesan, media pengajaran tidak hanya digunakan oleh pendidik, namun juga yang lebih penting dapat pula digunakan oleh peserta didik itu sendiri.

\section{METODE PELAKSANAAN}

Pelaksanaan kegiatan pengabdian kepada masyarakat ini menggunakan metode ceramah dan metode latihan praktek (drill practice) pembuatan media pembelajaran powtoon. Metode ceramah dilaksanakan dengan cara tim pengusul pengabdian datang ke sekretariat Gugus 1 Bogor Tengah Kota Bogor yaitu di SDN Pengadilan 5 Bogor Tengah, untuk sosialisasi pelatihan pengembangan pembuatan media pembelajaran Powtoon. Kegiatan ceramah ini dilaksanakan mengingat banyak guru mengalami kesulitan dalam menyampaikan materi pelajaran di kelasnya masing-masing pada saat proses pembelajaran berlangsung. Berdasarkan pendapat Sudjana (2011:86), metode drill adalah satu kegiatan melakukan hal yang sama, berulang-ulang secara sungguh-sungguh dengan tujuan untuk menyempurnakan suatu keterampilan agar menjadi permanen.

Gambaran langkah-langkah kegiatan pengabdian kepada masyarakat ini dapat dilihat pada gambar berikut. 


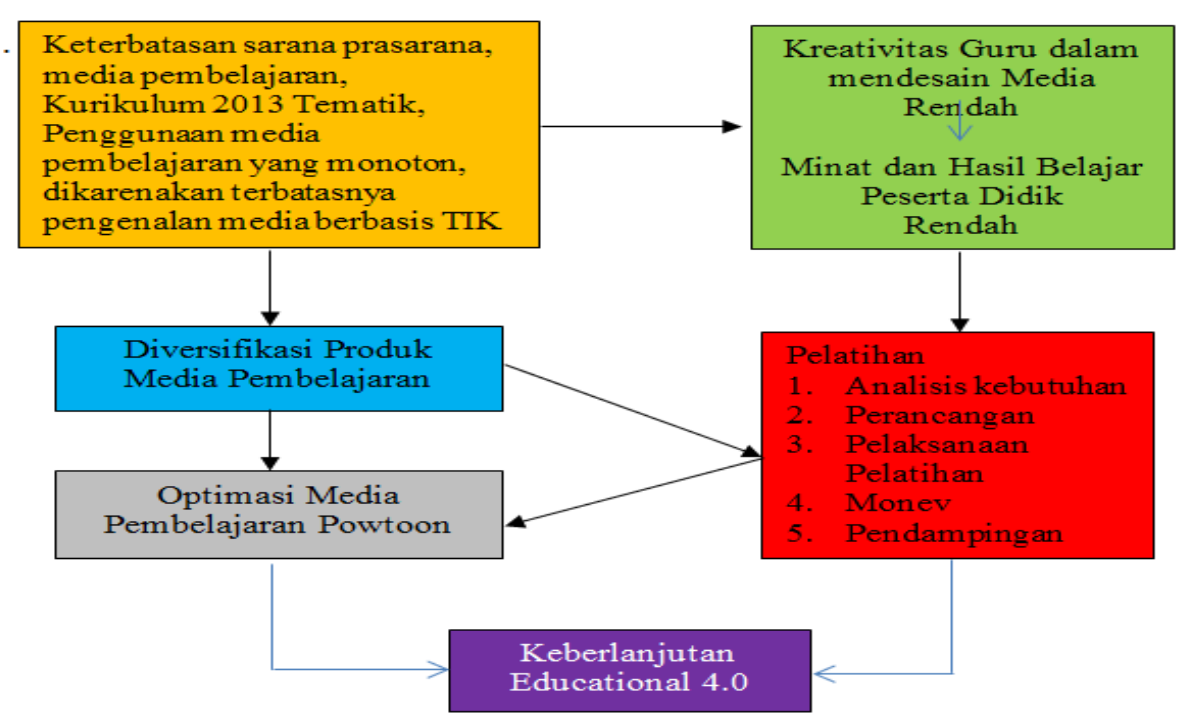

Gambar 1. Gambaran IPTEK Pendampingan Pembuatan Media Pembelajaran dengan Powtoon

\section{HASIL DAN PEMBAHASAN}

\section{Realisasi Pelaksanaan Kegiatan}

Pendampingan pembuatan media pembelajarn dengan powtoon ini diikuti oleh 34 orang guru kelas IV dan V Sekolah Dasar Gugus 1 Bogor Tengah Kota Bogor. Kegiatan konsolidasi dilaksanakan pada Akhir bulan Februari 2020. Setelah dilakuakan observasi awal, maka dilakukan diskusi dengan kepala sekolah sebagai mitra, dan guru bidang kurikulum yang ditunjuk oleh kepala sekolah. Tahap berikutnya adalah menentukan pelaksanaan pendampingan pembuatan media pembelajaran dengan powtoon, yang ditentukan pelaksanaannya pada hari Kamis, Jumat, dan Sabtu, tanggal 14, 15, dan 16 Mei 2020.

Pelaksanaan kegiatan dimulai pada pukul 08.00 sampai 15.00 WIB. Kegiatan pendampingan pembuatan media pembelajaran dengan powtoon bertujuan untuk memberikan pemahaman akan pentingnya penggunaan media pembelajaran sehingga para guru dapat membuat media pembelajaran dengan memanfaatkan teknologi dengan aplikasi atau program powtoon. Adapun rincian kegiatannya adalah :

1. Pemaparan materi dengan metode ceramah mengenai pentingnya penggunaan media pembelajaran dalam memotivasi dan meningkatkan hasil belajar siswa. Penggunaan media pembelajaran ini lebih mengutamakan pada pemanfaatan teknologi sesuai dengan era digital 4.0. Penjelasan materi ini berupa pengenalan program powtoon, toolbars yang ada pada program powtoon, kemudahan yang didapat dari penggunaan media pembelajaran dengan powtoon. Setelah itu penjelasan tentang cara-cara pembuatan materi ajar dengan powtoon yang menarik siswa untuk belajar, dengan memanfaatkan fitur-fitur yang ada pada aplikasi powtoon.

2. Pembagian kelompok kerja

Para guru dibagi ke dalam beberapa kelompok (masing-masing kelompok terdiri dari 2 orang) dan dibimbing oleh tim dosen serta mahasiswa. 
3. Praktik pembuatan media pembelajaran dengan powtoon.

a. Menyiapkan alat dan bahan yang diperlukan dalam pembutan materi dengan powtoon. (Laptop, Kurikulum, Buku Guru dan Buku Siswa)..

b. Mempelajari dan mendiskusikan bahan ajar atau materi yang akan dibuat ke dalam powtoon, sesuai dengan tema.

c. Menentukan desain yang sesuai dengan tema dan karakteristik siswa.

d. Memilih tema; dalam powtoon sudah ada tema bawaan yang bisa dipilih. Mulai memakai tema yang ada.

e. Memilih sesuaikan dalam tema ini, yaitu desain, gambar, background, dan huruf.

f. Membuat akun powtoon.

g. Pertama, masuk ke halaman utama powtoon dengan memasukan alamat www.powtoon.com di address bar internet browser.

h. Lalu klik login di pojok kanan atas dan pilih metode login yang akan digunakan. Setelah masuk, lalu klik Create a new Project. Pilih template yang diinginkan. Lalu masuk ke proses editing, klik got it dan edit semua slide yang terdapat dibagian kiri. Double klik pada teks untuk mengedit tulisan. Klik sound di bagian sisi kanan untuk menambahkan suara dan apply untuk menyimpan.

i. Tahap terakhir klik export untuk mempublish presentasi, pilih media untuk mempublish dan selesai.

Pendampingan ini mendapatkan respon positif terbukti dengan antusiasme guru dalam mengikuti dari awal sampai selesai. Meskipun PKM ini berbeda dari biasanya, yaitu menggunakan media online atau Webinar karena adanya Covid-19. Antusiasme dan kesiapan para guru menandakan bahwa adanya motivasi untuk pembelajaran yang lebih baik. Pada saat pemberian materi tentang pengenalan program powtoon ini, mereka banyak belajar, karena program ini merupakan program yang baru mereka kenal. Selama ini mereka mengajar hanya menggunakan media gambar diam, kalaupun diharuskan membuat slide powerpoint, mereka meminta bantuan orang lain. Kondisi itulah yang membuat para guru tersebut menerima dengan senang ketika diberikan pelatihan pembuatan media pembelajaran powtoon ini. Para guru menyadari bahwa kemajuan teknologi mengharuskan mereka untuk terus berinovasi dalam pembelajaran. Inovasi tersebut dapat dilakukan dengan pembuatan media yang disesuaikan dengan perkembangan teknologi. Penggunaan media pembelajaran powtoon ini tentu saja akan dapat menumbuhkan motivasi dan minat siswa dalam belajar, sehingga hasil belajar yang diharapkan akan tercapai. Oleh sebab itulah guru pada jaman ini dituntut untuk kreatif dan inovatif, sehingga menghasilkan siswa/peserta didik yang sesuai dengan tujuan pendidikan. Pada hari ketiga yang merupakan akhir pendampingan pembuatan powtoon ini, para guru yang terbagi dalam beberapa kelompok mempresentasikan hasil dari media pembelajaran yang telah dibuat. Hal ini membuktikan bahwa mereka serius dalam mengikuti pendampingan.

Data hasil pengabdian kepada Masyarakat ini diambil berdasarkan kuesioner yang telah dibagikan kepada guru-guru kelas III dan IV Gugus 1 Kota Bogor. Data mengenai karakteristik tanggapan responden dapat diketahui dalam tabel di bawah ini : 
Tabel Indikator Penilaian Pembuatan Media Pembelajaran dengan Powtoon.

\begin{tabular}{|c|c|c|}
\hline No & Indikator & $\begin{array}{l}\text { Jumlah Jawaban } \\
\text { Responden (nilai } \\
\quad \text { antara } 1-5 \text { ) }\end{array}$ \\
\hline 1 & Kesesuaian indikator dengan tingkat perkembangan siswa & 85 \\
\hline 2 & Indikator yang dipilih sesuaidengan kompetensi dasar & 82 \\
\hline 3 & $\begin{array}{l}\text { Penyajian materi bersifat interaktif sehingga memotivasi siswa } \\
\text { untukbelajar mandiri }\end{array}$ & 86 \\
\hline 4 & $\begin{array}{l}\text { Penyajian materi dengan media powtoon meningkatkan } \\
\text { motivasi belajar siswa }\end{array}$ & 82 \\
\hline 5 & $\begin{array}{l}\text { Susunan aktivitas dalam media powtoon mengarahkan peserta } \\
\text { didik untuk berfikir secara runtut berdasarkan tahapan 5M } \\
\text { (mengamati, menanya,mengumpulkan informasi, } \\
\text { mengasosiasi, mengomunikasikan). }\end{array}$ & 85 \\
\hline 6 & Materi yang disajiikan mudah untuk dipahami & 84 \\
\hline 7 & $\begin{array}{l}\text { Dengan menggunakan media powtoon memudahkan siswa } \\
\text { untuk belajar }\end{array}$ & 87 \\
\hline 8 & $\begin{array}{l}\text { Materi disajikan sesuai dengan perkembangan ilmu dan } \\
\text { teknologi }\end{array}$ & 84 \\
\hline 9 & Penggunaan media powtoon mengarahkan siswa lebih mandiri & 84 \\
\hline 10 & Tugas/soal latihan sesuai dengan rumusan indikator & 79 \\
\hline 11 & Tugas/soal latihan sesuai dengan materi yang disajikan & 82 \\
\hline 12 & Susunan kalimat dari tugas/soal latihan mudah dipahami & 81 \\
\hline 13 & Siswa dapat tanya tanya jawab mengenai materi yang disajikan & 88 \\
\hline 14 & $\begin{array}{l}\text { Meningkatkan pengetahuan siswaterhadap materi yang } \\
\text { disajikan }\end{array}$ & 82 \\
\hline 15 & $\begin{array}{l}\text { Dengan adanya media powtoonmeningkatkan keefektifan } \\
\text { siswa dalam belajar }\end{array}$ & 88 \\
\hline 16 & $\begin{array}{l}\text { Secara umum media pembelajaran mempunyai kualitas visual } \\
\text { (penampilan) dan suara (audio) baik }\end{array}$ & 81 \\
\hline 17 & $\begin{array}{l}\text { Media pembelajaran mencakup bahan untuk siswa dan guru } \\
\text { (panduan untuk guru dan LKS siswa) }\end{array}$ & 83 \\
\hline 18 & Isi media powtoon mengandung pesan yang ingin disampaikan & 88 \\
\hline 19 & $\begin{array}{l}\text { Isi media powtoon bersesuaian dengan tugas / aktivitas belajar } \\
\text { yang diberikan pada siswa }\end{array}$ & 84 \\
\hline 20 & Musik yang ditampilkan jelas dan tegas & 85 \\
\hline 21 & Ketepatan pemilihan jenis huruf & 87 \\
\hline 22 & Kemudahan pengoperasian media pembelajaran & 86 \\
\hline 23 & Menggunakan kata, istilah dan kalimat yang konsisten. & 85 \\
\hline 24 & Mempermudah proses pembelajaran & 86 \\
\hline 25 & Mempermudah guru dalam menyampaikan materi & 87 \\
\hline 26 & Mempermudah siswa memahami isi materi & 88 \\
\hline 27 & Komponen media powtoon diperjelas oleh komponen audio & 78 \\
\hline 28 & $\begin{array}{l}\text { Media pembelajaran powtoon dapat diakses dengan bantuan } \\
\text { teknologi atau aktivitas lainnya }\end{array}$ & 86 \\
\hline
\end{tabular}




\begin{tabular}{|c|c|c|}
\hline 29 & Media pembelajaran aman digunakan oleh siswa & 87 \\
\hline & JUMLAH & 2450 \\
\hline & RATA-RATA & 84 \\
\hline
\end{tabular}

Tabel 2 menunjukkan bahwa data diambil berdasarkan indikator seperti pada tabel di atas dengan rentang skor 1-5. Rata-rata perolehan nilai menunjukkan angka 84, artinya data tersebut dapat diartikan bahwa hampir 100\%, guru yang mengikuti pelatihan pembuatan media pembelajaran dengan powtoon dapat membuat materi sesuai dengan indikator. Dengan demikian media yang telah dibuat sudah selayaknya dapat digunakan dalam proses pembelajarn, agar dapat memotivasi siswa. Berikut hasil angket pelatihan pembuatan media pembelajaran dengan powtoon yang dibuat dalam bentuk grafik.

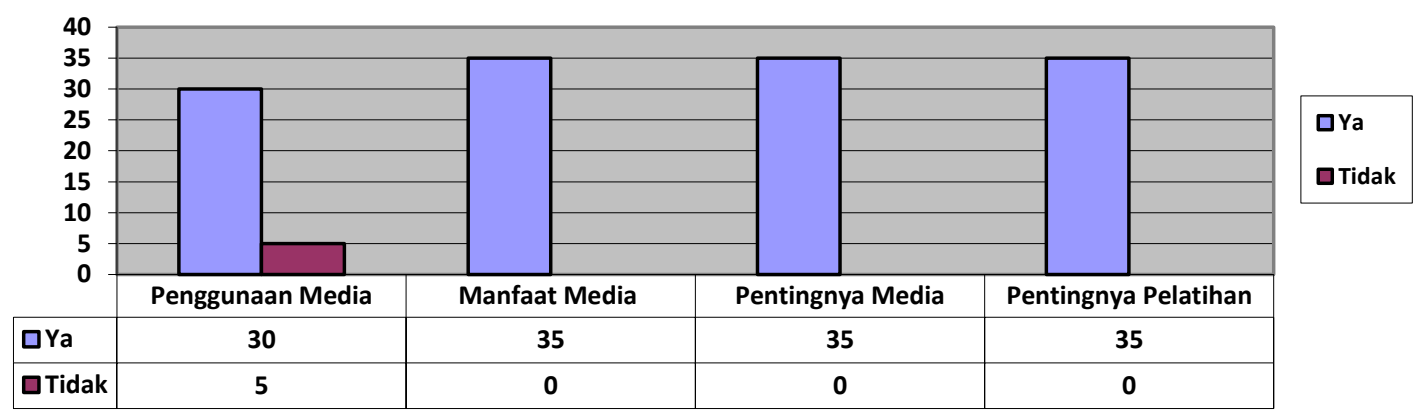

Gambar 2 Tanggapan Guru sebelum dan sesudah diberikan Pendampingan

Mengacu pada gambar 2 dapat diketahui bahwa sebanyak 5 dari 35 responden menyatakan tidak menggunakan media pembelajaran baik proyeksi ataupun non proyeksi. Jawaban tidak, dapat dipahami karena fasilitas atau sarana yang mendukung pada penggunaan media masih kurang. Namun secara keseluruhan dari 35 guru yang mengikuti pelatihan, memahami akan manfaat penggunaan media pembelajaran baik yang diproyeksikan maupun non proyeksi. Mereka memahami manfaat penggunaan media pembelajaran terutama media pembelajaran powtoon ini dapat membantu pemahaman siswa yang masih dalam tahap kongkret. Dalam arti siswa usia sekolah dasar memahami suatu materi ajar harus disertai dengan penjelasan yang kongkret. Data di atas menunjukkan bahwa pihak sekolah perlu memberikan fasilitas yang mendukung akan keberhasilan pembelajaran. Adanya usaha atau upaya yang dilakukan guru kurang berhasil, dikarenakan kurangnya dukungan dari pihak sekolah ataupun pemerintah daerah. Dalam hal penggunaan media berbasis ICT ini diperlukan fasilitas berupa komputer, laptop, LCD dan tentu saja jaringan internet. 35 responden sangat mengharapkan akan adanya pelatihan lanjutan, sehingga mereka akan lebih maksimal dalam memberikan pembelajaran. Pentingnya sarana prasarana media pembelajaran berbasis ICT atau TIK ini sesuai dengan penelitian yang diteliti oleh Novita, dkk. (2020) yang menunjukkan bahwa sarana prasarana pada sekolah dasar di kota Bogor masih belum lengkap terutama yang berbasisi TIK/ICT. Namun dalam penggunaan media pembelajaran yang dapat meningkatkan hasil belajar dan menumbuhkan motivasi belajar ditemukan pada hasil penelitian salah satunya dalam jurnal penelitian Sukmanasa, Novita, dan Majid. (2019), yang menemukan bahwa penggunaan media pembelajaran meningkatkan hasil belajar terutama pada sub tema manusia dan lingkungan. Oleh sebab 
itu pelatihan dan pendampingan pada guru mengenai pentingnya penggunaan media pembelajaran perlu terus dilakukan.

Berikut foto kegiatan dan hasil pelatihan pendampingan pembuatan media pembelajaran dengan powtoon.

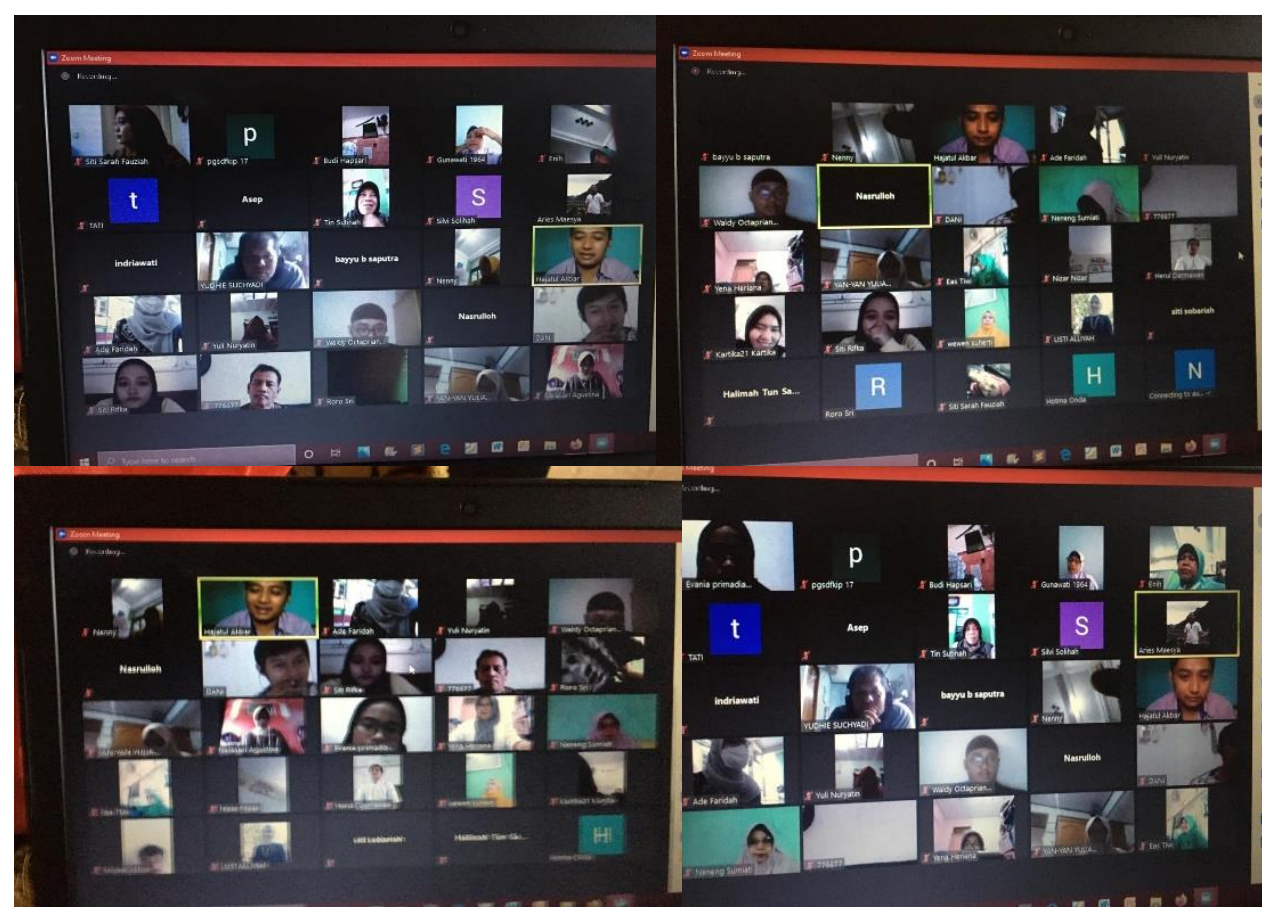

Gambar 3 Foto Pelatihan Pendampingan Pembuatan Media Pembelajaran dengan Powtoon

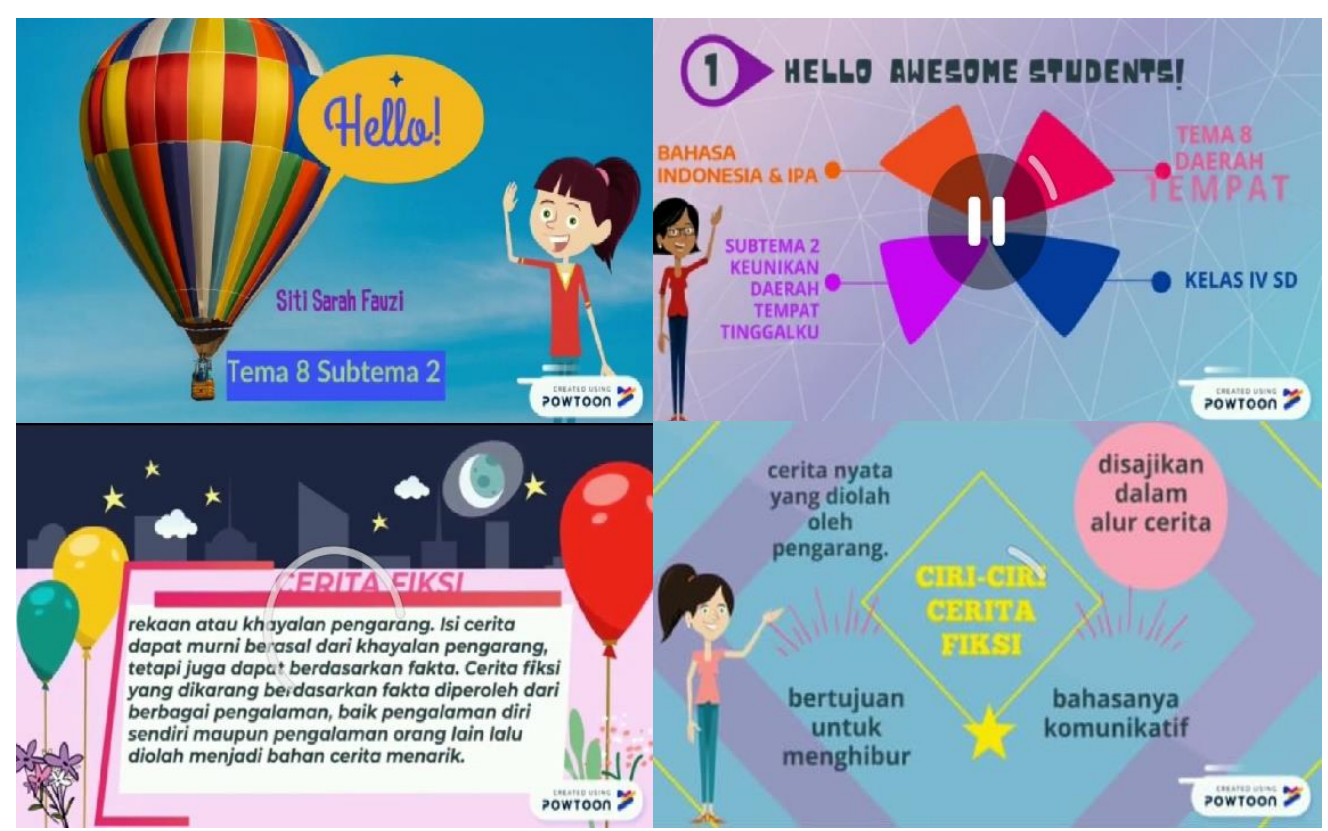

Gambar 4 Foto Hasil Pelatihan Pendampingan Pembuatan Media Pembelajaran dengan Powtoon 


\section{SIMPULAN}

Pelatihan dan pendampingan yang merupakan pengabdian kepada masyarakat ini dilakuakan dengan menggunakan media webinar atau online. Hal ini disebabkan adanya kondisi Covid-19, namun kondisi tersebut tidak mengurangi antusiasme guru dalam mengikuti pelatihan pendampingan ini.

Pengabdian kepada masyarakat ini akan erat kaitannya dengan pembelajaran yang merupakan muatan perkuliahan di Fakultas Keguruan dan ilmu pendidikan Universitas Pakuan, yang direncanakan untuk jangka panjang hingga 20 tahun mendatang. Hal ini karena PKM didukung oleh penerapan media pembelajaran berupa TIK. Teknologi komputer tersebut dikemas menjadi salah satu media untuk mendukung penguatan keberlanjutan dan revitalisasi media pembelajaran. Media pembelajaran berbasis IT berupa Powtoon ini akan menarik dan menjadi motivasi siswa dalam belajar. Tujuan akhir dari hal ini adalah meningkatnya minat siswa sebagai generasi milineal penerus bangsa agar aktif dalam proses pembelajaran sehingga penguatan tujuan pendidikan dapat tercapai sesuai dengan harapan.

Pentingnya pelatihan dan pendampingan pada guru mengenai penggunaan media pembelajaran perlu terus dilakukan. Hal ini berkenaan dengan pembelajaran yang sesuai platform RI 4.0. Pembelajaran dengan platform RI 4.0 mengharuskan guru atau pendidik untuk berinovasi dalam pembelajaran, sehingga kualitas pembelajaran akan semakin baik dalam menciptakan peserta didik yang berkualitas.

\section{DAFTAR PUSTAKA}

Andrianti, Yeni., L.R. Retno Susanti, Hudaidah. (2016). Pengembangan Media Powtoon Berbasis Audiovisual Jurnal Criksetra, Volume 5, No 9. Tersedia http://ejournal2.unsri.ac.id/index.php/criksetra/article/viewFile/4802/2548.

Awalia, Izomi, Aan Subhan Pamungkas, Trian Pamungkas Alamsyah. (2019). Pengembangan Media Pembelajaran Animasi Powtoon pada Mata Pelajaran Matematika di Kelas IV SD. Kreano Jurnal Matematika Kreatif-Inovatif. Vol.10 No.1. Tersedia DOI: https://doi.org/10.15294/kreano.v10i1.18534

Fajar, Syahrul. Riyana, Cepi, dan Hanoum, Nadia. (2017). Pengaruh Penggunaan Media Powtoon Terhadap Hasil Belajar Siswa Pata Mata Pelajaran Ilmu Pengetahuan Sosial Terpadu. Jurnal Edutcehnologia, 3(2), 101-114.

Fitriyani, Nina. (2019). Pengembangan Media Pembelajaran Audio-Visual Powtoon Tentang Konsep Diri Dalam Bimbingan Kelompok Untuk Peserta Didik Sekolah Dasar. Jurnal Tunas Bangsa. Vol. 6. No. 1. Tersedia https://tunas bangsa. stkipgetsempena.ac.id.

McLuhan, Marshall. (2006.) The Medium is the Message. United Kingdom : Blackwell.

Muslimin, Muhammad Ikhwanul. (2017). Pengaruh Penggunaan Media Pembelajaran Video Animasi Terhadap Hasil Belajar Pendidikan Kewarganegaraan Kelas II 
SD. E-Jurnal Prodi Teknologi Pendidikan Vol. VI No. 1. Tersedia journal.student.uny.ac.id>ojs>index.php〉fiptp>article

Novita, Lina, Windiyani, Tustiyana. Fazriani, Rifa. (2019). Pengembangan Media Pembelajaran Berbasis ICT Pada Subtema Bersyukur Atas Keberagaman Untuk Siswa Kelas IV Sekolah Dasar JPPGuseda| Jurnal Pendidikan \& Pengajaran Guru Sekolah Dasar. Vol.2 No. 2. Halaman 82-86.

Novita, Lina, Windiyani, Tustiyana, Fauziah, Siti Sarah. (2020). Analisis Pemanfaatan Media Pembelajaran Berbasis TIK di Sekolah Dasar Negeri Pengadilan 5 Kota Bogor. JPI (Jurnal Pendidikan Indonesia): Jurnal Ilmiah Pendidikan.Vol.6 No.1. 2443-3268

Nurdiansyah, Edwin, Emil El Faisal, Sulkipani. (2018). Pengembangan media pembelajaran berbasis PowToon pada perkuliahan Pendidikan Kewarganegaraan. Vol.15 No.1. Jurnal Civic. Media Kajian Kewarganegaraan. Tersedia di. https://journal.uny.ac.id/index.php/civics/ article/view/16875.

Pengetahuan Sosial Terpadu. Edutcehnologia, Tahun 3, Vol 3 No. 2. Tersedia ejournal.upi.edu > index.php > edutechnologia > article > download > pdf_1.

Ponza, Putu Jerry Radita, I Nyoman Jampel, I Komang Sudarma. (2018). Pengembangan Media Video Animasi Pada Pembelajaran Siswa Kelas IV Di Sekolah Dasar. Jurnal Jurusan Teknologi Pendidikan. Vol. 9 No. (2) pp. 8-18. Tersedia https://ejournal.undiksha.ac.id> index.php>JEU> article>

Rio Ariyanto, Sri Kantun, Sukidin. (2018). Penggunaan Media Powtoon Untuk Meningkatkan Minat Dan Hasil Belajar Siswa Pada Kompetensi Dasar Mendeskripsikan Pelaku-Pelaku Ekonomi Dalam Sistem Perekonomian Indonesia. Jurnal Pendidikan Ekonomi: Jurnal Ilmiah Ilmu Pendidikan, Ilmu Ekonomi, dan Ilmu Sosial 122 ISSN 1907-9990 |E-ISSN 2548-7175 | Volume 12 Nomor 1 (2018) DOI: 10.19184/jpe.v12i1.7622

Sudjana, Nana. (2011). Penilaian Hasil dan Proses Belajar Mengajar. Bandung: Rosda Karya

Sukmanasa, Elly., Windiyani, Tustiyana., Novita, Lina. (2017). Pengembangan Media Pembelajaran Komik Digital Pada Mata Pelajaran Ilmu Pengetahuan Sosial Bagi Siswa Kelas V Sekolah Dasar Di Kota Bogor. Jurnal JPSD Untirta. Vol.3 No.2. Tersedia pada http://jurnal.untirta.ac.id/index.php/jpsd/article/view/2138.

Sukmanasa, Elly, Novita, Lina, Majid, Rifki Abdul. (2019). Use Of Learning Video Media On Human And Environmental Subthema. JHSS (Journal Of Humanities And Social Studies). Vol. 3 No. 2. 72-75

Suparman. (2010). Gaya Mengajar yang Menyenangkan Siswa. Yogyakarta: Pinus Book Publisher. 